\title{
THE TRAINING AND CAREERS OF THOSE APPRENTICED TO APOTHECARIES IN SUFFOLK $1815-1858$
}

by

DAVID VAN ZWANENBERG*

IN the first half of the nineteenth century, the medical requirements of the people of Suffolk were served by about 170 general practitioners, ${ }^{1}$ who were both surgeons and apothecaries but usually referred to as surgeons. Eleven of these men had acquired doctorates in medicine from Scottish or European universities some years after starting practice, but, apart from using the title of Doctor, this did not alter the nature of their work nor prevent them from accepting surgical apprentices.

There are also listed in the Suffolk Directory ${ }^{2}$ twelve other doctors of medicine, one of whom (J. Kirkman) was the Medical Superintendent of the County Lunatic Asylum, and a further three lived as gentlemen on their country estates. ${ }^{3}$ The remaining eight, who all lived in Ipswich or Bury St Edmunds, seem to have practised as true physicians in that they were: (1) medical advisers to the gentry; ${ }^{4,5,6}(2)$ on the staff of local hospitals as physicians; ${ }^{7-13}(3)$ available for consultation with the surgeons; $;^{14-17}$ (4) medical visitors to the private madhouse. ${ }^{18-21}$ Also, they did not have apprentices nor did they practise midwifery and surgery. Only one physician in Suffolk during the

* David van Zwanenberg, DM, MA, DCH, DPH, Consultant Physician, The Ipswich Hospital, St Helen's Wing, Foxhall Road, Ipswich IP3 8LY.

${ }^{1}$ William White, History, gazeteer and directory of Suffolk, 1st ed., Sheffield, [the author], 1844.

2 Ibid.

${ }^{3}$ There is no evidence that they practised.

4 Ipswich Journal, 3 February 1855.

Ibid., 21 April 1860.

- R. B. Beckett (editor), The family at East Bergholt. John Constable's correspondence, London, HMSO, 1962, p. 120 (Ann Constable's letter to John Constable, 14 March 1815).

'Robson's commercial directory of the six counties forming the Norfolk Circuit, 1839, Suffolk: pp. $1-102$.

J. W. E. Cory, A short history of the Suffolk General Hospital, Bury St Edmunds, Suffolk Record Office, 1973.

'Ipswich Journal, 26 November $1825 . \quad 13$ Ibid., 24 December 1842.

10 Ibid., 17 January 1829.

11 Ibid., 25 April 1840.

14 Ibid., 16 February 1856.

12 Ibid., 8 July 1840.

15 Ibid., 23 August 1856.

16 Ibid., 28 August 1858.

17 Beckett (editor), op. cit., note 6 above, p. 121 (Martha Constable's letter to Mrs Constable, 24 March 1815).

18 Ipswich Journal, 25 October 1845.

19 Ibid., 9 September 1848.

20 Ibid., 26 October 1850.

21 Ibid., 23 August 1851. 


\section{D. van Zwanenberg}

period 1800-1850 became a Fellow of the Royal College of Physicians and that was Dr W. H. Williams of Ipswich who was elected FRCP in 1817 and retired from practice in $1835 .^{22,23}$ During this period there were between $174^{1}$ and $169^{24}$ surgeons practising in Suffolk, who must therefore have been responsible for well over ninety per cent of the medical work in the county, ${ }^{25}$ and the influence of the physicians must have been slight. The disagreements among physicians, surgeons, and apothecaries that troubled the medical profession in London had no equivalent in Suffolk. ${ }^{26}$

It is hoped that this study of those who trained to be medical practitioners in Suffolk during this period will give some idea of the quality of medical practice in this rural area, and that the discovery of what this training enabled these men to achieve in later life will demonstrate the usefulness of the Apothecaries' Act of 1815.

This Act was the first attempt to regulate the general practice of medicine by requiring those aspiring to practise to be regularly apprenticed to a recognized apothecary for a minimum of five years and then to attend lectures and a recognized hospital or dispensary. Originally, courses in Anatomy, Theory and Practice of Medicine, Pharmaceutical Chemistry, and Materia Medica were all that was required. ${ }^{27}$ These requirements were increased to include Physiology and Medical Botany (1816), Demonstrations in Anatomy and the Principles and Practice of Midwifery (1827), Clinical Lectures (1828), and Forensic Medicine (1836). Then, provided he was aged twenty-one or more, the apprentice obtained his licence to practise by passing an oral examination at Apothecaries' Hall in London.

All the names and addresses of those who sat this examination, together with the names and addresses of their masters and the name of the hospital they attended, were recorded and are still available for inspection. It has been claimed that little use has been made of this material. ${ }^{27}$ In this paper the details of those apprenticed in Suffolk between 1815 and 1858 have been obtained and an attempt made to trace these men through their "medical training", to discover where and how they practised, and what they achieved in their careers.

\section{THE TRAINING}

During the period 1815-1858, 330 apprentices completed their training in Suffolk, attended hospitals or dispensaries, satisfied the examiners, and were admitted licentiates of the Society of Apothecaries (LSA). The period of apprenticeship was recorded and was usually five years $(297=90$ per cent), but thirteen (3.9 per cent) of the pupils served for six years and nineteen (5.8 per cent) for seven years. For no obvious reason, one pupil was allowed to take the examination after only four years.

${ }^{22} \mathrm{~W}$. Munk, The roll of the Royal College of Physicians of London, London, Royal College of Physicians, 1878, vol. 2, pp. 169-171.

${ }^{23} \mathrm{DNB}$.

24 White, op. cit., note 1 above, 2nd ed., Sheffield, 1855.

${ }^{25} \mathrm{John}$ Mason Good, The history of medicine, so far as it relates to the profession of the apothecary, London, 1795, pp. 146-147: "Where a physician attends one patient, an apothecary attends twenty, and in the country, this proportion is more than double." John Mason Good had practised as an apothecary in Sudbury, Suffolk, 1784-1793.

${ }^{26}$ S. W. F. Holloway, 'The Apothecaries' Act, 1815: a reinterpretation', Med. Hist., 1966, 10: 107-129.

${ }^{27}$ MSS of the court of examiners, the Society of Apothecaries. Guildhall Library, City of London, 1815-1858. 


\section{Training and careers of Suffolk apothecaries' apprentices}

From 1823 onwards, the age of the pupil was recorded, either at the time of the examination or as his date of birth or date of baptism. Table 1 shows the ages when 259 of the pupils began their apprenticeship. A large majority $(224=86.5$ per cent $)$ started their training between the ages of fifteen and twenty.

TABLE 1

AGE OF PUPIL AT THE START OF HIS APPRENTICESHIP, 1823-1858

\begin{tabular}{ccc} 
& Age at start & Number of pupils \\
& 14 & 3 \\
15 & 6 \\
16 & 49 \\
17 & 61 \\
18 & 56 \\
& 19 & 39 \\
& 20 & 13 \\
\multirow{6}{*}{ More than } & 21 & 7 \\
& 22 & 8 \\
& 23 & 6 \\
& 23 & 11 \\
& & 259
\end{tabular}

Table 2 shows where the pupils lived and the populations where they worked. The small towns (pop. 2000-5500) seem to have been the most popular with 141 (42.7 per cent) apprentices, whereas the two large towns of Ipswich and Bury St Edmunds had only sixty-four (19.4 per cent) apprentices between them in the course of forty-three years. On average, therefore, there would have been about six apprentices at a time in Ipswich and about four in Bury St Edmunds. Although the small towns had relatively more pupils ( 2.85 per 1,000 population compared with 1.7 for the large towns), there can rarely have been more than three pupils at a time in any of these places. In the villages, an apprentice can seldom have met with his fellows unless he made special arrangements, which probably involved him riding for some miles. In these small communities, the apprentice must have been very dependent on his master for instruction, practical experience, and even simple companionship. If the master was lazy, an alcoholic, or more interested in farming, then the pupil's lot must have been unhappy indeed, as happened to the poet George Crabbe in the late eighteenth century. ${ }^{28,29}$

In theory, the large towns had certain advantages for surgical apprentices. In addition to the number of pupils likely to be training simultaneously, giving the possibility of discussion, seminars, etc., two general hospitals were founded during the period and these were preceded by medical dispensaries supplying out-patient treatment for the poor. ${ }^{30,31}$

The Suffolk General Hospital was opened at Bury St Edmunds in 1826, ${ }^{32}$ and the

G. Crabbe, The life of George Crabbe, London, Cresset Press, 1947.

${ }^{29} \mathrm{~N}$. Blackburne, 'The restless ocean.' The story of George Crabbe, the Aldeburgh poet (1754-1832), Lavenham, Terence Dalton, 1972.

${ }^{30}$ Annual reports of Ipswich Public Dispensary, published each April in the Ipswich Journal, 1795-1835.

${ }^{31}$ Cory, op. cit., note 8 above, p. 10.

32 Ibid. 


\section{D. van Zwanenberg}

TABLE 2

LOCATION AND NUMBER OF APPRENTICES WITH POPULATIONS AS IN THE 1841 CENSUS

\begin{tabular}{|c|c|c|c|c|c|}
\hline Location & Population & $\begin{array}{c}\text { No. of } \\
\text { apprentices } \\
1815-1858\end{array}$ & Location & Population & $\begin{array}{c}\text { No. of } \\
\text { apprentices } \\
1815-1858\end{array}$ \\
\hline Aldeburgh & 1,557 & 1 & Lavenham & 1,871 & 1 \\
\hline Bacton & 800 & 1 & Laxfield & 1,172 & 3 \\
\hline Barrow & 995 & 1 & Long Melford & 2,597 & 6 \\
\hline Beccles & 4,086 & 22 & Lowestoft & 4,647 & 12 \\
\hline Bildeston & 857 & 9 & Mendham & 566 & 1 \\
\hline Botesdale & 633 & 1 & Mendlesham & 1,340 & 2 \\
\hline Boxford & 889 & 4 & Nayland & 1,114 & 7 \\
\hline Bungay & 4,109 & 16 & Needham Mkt & 1,353 & 3 \\
\hline Bures & 984 & 1 & Newmarket & 2,956 & 7 \\
\hline Bury St Edmunds & 12,538 & 25 & Norton & 879 & 10 \\
\hline Clare & 1,550 & 1 & Orford & 1,109 & 1 \\
\hline Coddenham & 653 & 1 & Saxmundham & 1,097 & 12 \\
\hline Creeting St Mary & 196 & 2 & Shottisham & 283 & 1 \\
\hline Debenham & 1,667 & 5 & Stanton & 1,029 & 2 \\
\hline Earl Soham & 741 & 2 & Stowmarket & 3,043 & 16 \\
\hline East Bergholt & 1,461 & 1 & Stratford St Mary & 647 & 1 \\
\hline Eye & 2,493 & 2 & Sudbury & 5,085 & 9 \\
\hline Framlingham & 2,523 & 6 & Thetford & 3,934 & 3 \\
\hline Gedding & 173 & 1 & Waldringfield & 676 & 1 \\
\hline Gorleston & 2,351 & 1 & Walsham le Willows & 1,265 & 2 \\
\hline Grundisburgh & 874 & 1 & Walton & 907 & 3 \\
\hline Hadleigh & 3,911 & 14 & Wangford & 690 & 7 \\
\hline Halesworth & 2,662 & 11 & Wickham Mkt & 1,400 & 4 \\
\hline Hartest & 811 & 5 & Wickhambrook & 1,623 & 1 \\
\hline Holbrook & 747 & 7 & Witnesham & 543 & 2 \\
\hline Hollesley & 590 & 1 & Woodbridge & 4,954 & 16 \\
\hline Hopton & 251 & 2 & Woolpit & 942 & 2 \\
\hline Ipswich & 25,254 & 39 & Wrentham & 1,020 & 3 \\
\hline Ixworth & 1,064 & 1 & Yoxford & 1,251 & 6 \\
\hline
\end{tabular}

One apprentice is not included as his location was listed simply as Suffolk.

East Suffolk and Ipswich Hospital followed in $1836 .{ }^{33}$ In time, both hospitals played a major part in maintaining the standard of medical practice in the area but there is little evidence that they had any effect on the training of apprentices. The house surgeon at each hospital was permitted to have an apprentice, but surprisingly only four were ever appointed, three at the Suffolk General and only one at the East Suffolk and Ipswich Hospital. ${ }^{27}$

Another advantage for apprentices living in or near Ipswich was the founding in 1824 of the Suffolk Medical Book Society. ${ }^{34}$ This society ran a small medical library, both of textbooks and journals, in the back room of an Ipswich bookshop. Subscribing members and their apprentices had the right to visit, borrow books, or have them sent by post. Even though membership was confined to those living within twelve miles of Ipswich, fifty-eight of the surgeon apothecaries who trained apprentices were members of this society.

The 330 apprentices were trained by 128 surgeons, but very few of these masters

${ }^{33}$ Ipswich Journal, 26 August 1836.

${ }^{34}$ Suffolk Medical Book Society, minute books. East Suffolk Record Office, County Hall, Ipswich. 
had more than one pupil at a time, and in fact, fifty-nine of them only had one pupil altogether. Even the few apothecaries who trained six pupils or more seem to have arranged their apprenticeships so that there was only a limited overlap between one apprentice and the next. Only eight of the surgeon apothecaries managed to train seven or more pupils. These men advertised regularly for apprentices in the local newspaper and must have arranged their practices and their households to accept the pupils as a matter of routine, whereas those who just had an occasional pupil cannot have been so organized. Special attention has therefore been paid to these eight masters, who are now considered individually. Two of them had as many as ten apprentices each. The first of these, W. C. Worthington of Lowestoft, had a very large practice in the north of the county and was senior surgeon to the Lowestoft Infirmary when it was opened in $1840 .{ }^{35}$ Worthington started practice in 1820 , and took on a new apprentice about every three and a half years, so that his last apprentice left Lowest oft for London in 1856. He was acknowledged as a skilful and competent surgeon and as such was elected a Fellow of the Royal College of Surgeons in 1844. ${ }^{36}$ In addition, he became interested in pathology and presented his collection of specimens to the Lowestoft Infirmary in 1849.37

The other man who trained ten apprentices was Dr James Bedingfield of Stowmarket, who advertised from $1825^{38}$ that he ran a medical academy and was willing to receive a number of young gentlemen for preparation for the medical profession, by combining apprenticeship with instruction in medical anatomy, surgical demonstrations, etc. He became well known in the Eastern Counties and presented a number of surgical cases to both the Eastern, ${ }^{39}$ and the Suffolk ${ }^{40}$ Branches of the Provincial Medical and Surgical Association. As he retired from practice in $1850,{ }^{41}$ he had trained his ten pupils in the course of twenty-five years - unlike most of his contemporaries, he was prepared to have two or three pupils at the same time. ${ }^{27}$ One of his surgical colleagues, W. Hempson Denham of Wickham Market, dedicated a book concerning the training of medical students to James Bedingfield as follows: "Not only have you endeavoured ... to amend the present and futile method of medical study, but you have also established what ... till originated by you, had never before existed in the County of Suffolk nor indeed in but few other counties ... a well regulated ... and an efficient system of private initiatory medical instruction". 42

Three surgeons trained eight apprentices each. They were W. H. Crowfoot of Beccles; ${ }^{43}$ and John Grouse ${ }^{44,45}$ and William Mudd ${ }^{46,47}$ of Hadleigh. These three men

${ }^{35}$ White, op. cit., note 1 above.

${ }^{36}$ V. G. Plarr, Lives of the Fellows of the Royal College of Surgeons of England, vol. 2, Bristol, John Wright, 1930.

${ }^{37}$ Ipswich Journal, 20 January 1849.

${ }^{36}$ Ibid., 21 May 1825.

* Ibid., 11 January 1836.

39 Ibid., 15 January 1844.

41 Ibid., 12 January 1850.

${ }^{42} \mathrm{~W}$. Hempsom Denham, Verba consilia or hints to parents who intend to bring up their sons to the medical profession, London, John Churchill, 1837.

${ }^{43}$ A. E. Crowfoot, The Crowfoots of Beccles, Beccles, [privately printed], 1959.

4 F. S. Growse, Material for a history of the parish of Bildeston, [privately printed], 1892.

as Ipswich Journal, 25 March 1818.

“ Ibid., 1 January 1833.

${ }^{4}$ Ibid., 2 October 1841. 


\section{D. van Zwanenberg}

had various features in common; they all came from surgical families and had themselves been apprenticed to close relatives; they all had sons who became surgical apprentices in their turn. John Grouse apprenticed his son to a surgeon in Ipswich, but the other two trained their own sons. Consequently, all three must have known all the potential apprentices in their districts over many years, and their family names must have been equally well known to aspiring apprentices.

The three surgeons who had seven apprentices each were all well known in Suffolk as skilful surgeons. John Denny of Ipswich had had considerable surgical experience in the army, ${ }^{4}$ which he had joined as a surgeon's mate in 1795 and finally served as surgeon to the 62nd Foot during the retreat to Corunna in 1809. His seven apprentices were spread over twenty years, as he died in 1835 . In addition to instructing his own pupils, he allowed all surgical apprentices in the district to attend his surgery in "Denny's Passage" which became the gathering point for all those involved in surgery. Denny was a man with considerable influence in Ipswich, serving the town for some years as chief magistrate, and he has an exceptional record in that all seven of his apprentices settled to practise in Ipswich after qualification, comprising twentyfive per cent of the next generation of surgeons in that town. ${ }^{49,50}$

Robert Carew King was the son of a former headmaster of Ipswich School, where he was educated. ${ }^{51}$ He was then apprenticed to a surgeon in Ipswich, but practised for forty-five years in Saxmundham where he had a considerable local reputation as a surgeon and lithotomist. ${ }^{32}$ As such, he assisted William Jeaffreson to carry out the first successful ovariotomy in England, 33 and later performed a similar operation by himself. His name is still remembered in Saxmundham where his bust can be seen in the local surgery. ${ }^{\text {st }}$

Little has been written about Henry Lay of Wangford, who was the third man to have seven apprentices. He had a local reputation as an efficient surgeon and was on the staff of the Southwold Medical Dispensary, ${ }^{55}$ some ten miles from his home.

One village, Norton, had ten apprentices during the period, but this was not due to the reputation of a particular surgeon as three surgeons served this community during that time. The first, Benjamin Clayton, died in 1819, and the practice was taken on by one of his own apprentices, Plowman Young, who had obtained his LSA in 1818. Young developed tuberculosis, and after training five apprentices moved to Bury St Edmunds, Thomas Barsham taking over the practice. It is not clear why Norton attracted this number of apprentices.

W. Johnston, Roll of commissioned officers in the Medical Service of the British Army 1727-1898, Aberdeen University Press, 1917, no. 2257. (Reprinted, London, Wellcome Institute for the History of Medicine, 1968.)

- J. Glyde, Official directory, almanac and annual, Ipswich, 1881. (Recollections of old Ipswich: (1) Our medical men.)

so W. A. Elliston was the son of one of Denny's apprentices and wrote an account of him in the minute book of the Suffolk Medical Book Society (op. cit., note 34 above).

s1 William King, MD, (brother of R. C. King), 'Autobiography', MS in East Suffolk Record Office, County Hall, Ipswich.

32 [Obituary] R. C. King, Gentleman's Magazine, 1883, pp. 213-215.

s3 W. Jeaffreson, Trans. Prov. Med. Surg. Ass., 1837, 5: 239-245.

s4 Dr D. Ryder Richardson, personal communication.

ss Ipswich Journal, 23 September 1837. 


\section{Training and careers of Suffolk apothecaries' apprentices}

Some idea of the life of a surgical apprentice in East Anglia at this time can be gained from the biography of Sir James Paget, ${ }^{36}$ who was an apprentice in Great Yarmouth from 1830 to 1835 . In his opinion, the period of the apprenticeship was far too long. Although he learned dispensing, a practical knowledge of medicines, account keeping, organization of the practice, and the essential elements of anatomy, he described his daily work as dull and "at times tedious and apparently useless". He was required to stay in the surgery every day 9.0 a.m. to 1 p.m. and 2 p.m. to 5 p.m., his time was occupied by dispensing, seeing a few out-patients of the poorer class, receiving messages, making appointments, and once a year making out the bills. When his master returned from his rounds, it was the pupil's task to write at his dictation the details of any visit and any prescriptions which had to be made up and despatched later. Specific instruction was difficult to obtain, so during his second year Paget used to ride ten miles to Acle each week to attend an anatomy class. Since Paget was intelligent, energetic, and had time to spare, he taught himself botany and zoology and with his brother wrote a book on the subject. ${ }^{37}$

Another surgeon who left detailed descriptions of his work as an apprentice was John Green Crosse who was a pupil in Stowmarket, Suffolk, 1806-1811. ${ }^{58,59} \mathrm{His}$ experience was similar to Paget's because he had plenty of time to visit any entertainments in the district and his work was light enough for his master, Thomas Bayly, to loan his apprentice to his brother, John Bayly, a surgeon in Swaffham, Norfolk, for several weeks each year. In spite of this increase in his experience, John Crosse, who recorded every interesting case that he saw throughout his career, was only able to describe fifty-one such cases during his five-year apprenticeship. ${ }^{60}$

Having completed five years' apprenticeship, all the pupils had to attend a medical institution, hear the necessary lectures, and gain further practical experience. Of the 330 Suffolk apprentices, 295 (89.4 per cent) went to London for this further education, thirteen (3.94 per cent) went to Scotland (Edinburgh 7, Glasgow 4, Aberdeen 2), and one attended the Hôpital de la Charité in Paris. In eight cases, the place of attendance was not recorded. In the years immediately following the Apothecaries' Act, the examiners allowed a few apprentices to include attendance at East Anglian institutions, thus two attended the Norfolk and Norwich Hospital, one went to Addenbrooke's Hospital, Cambridge, one was allowed to use his experience at the Workhouse Infirmary at Barham, Suffolk, and another his experience at the Framlingham Dispensary, also in Suffolk. For those who attended institutions in London, there were a limited number of hospital places in the early years, so many of the pupils worked in out-patient dispensaries. After 1837, both University College Hospital and King's College Hospital took medical students. This change is illustrated in Table 3 -

s6 S. Paget, Memoirs and letters of Sir James Paget, London, Longmans, Green, 1901.

"17. J. Paget and J. Paget, $A$ sketch of the natural history of Yarmouth and its neighbourhood, containing catalogues of the species of animals, birds, reptiles, fish, insects and plants, at present known, Yarmouth, F. Skill, 1834.

so V. M. Crosse, $A$ surgeon in the early nineteenth century, Edinburgh and London, E. \& S. Livingstone, 1968.

s9 J. G. Crosse, journal, 1806-1811, MSS nos. 465, 466, 467. Norfolk and Norwich Record Office, Norwich.

co J. G. Crosse, case book (Stowmarket), MS no. 5249. Ibid. 


\section{D. van Zwanenberg}

in the period 1815-1837, fifty-four per cent of the London-bound pupils attended hospitals, whereas ninety-nine per cent had this experience after 1838.

TABLE 3

PLACES OF FURTHER TRAINING IN LONDON FOR SUFFOLK PUPILS COMPARING PERIODS 1815-1837 WITH 1838-1858

\begin{tabular}{|c|c|c|}
\hline Dispensaries & $1815-1837$ & $1838-185$ \\
\hline General Dispensary & 19 & $1000-100$ \\
\hline Surrey Dispensary & 36 & 1 \\
\hline London Dispensary & 4 & - \\
\hline South London Dispensary & 5 & - \\
\hline Marylebone Dispensary & 6 & - \\
\hline St George and St James & 6 & - \\
\hline Chelsea and Brompton & 1 & - \\
\hline Kent Dispensary & 1 & - \\
\hline Western Dispensary & 3 & - \\
\hline Total & 81 & 1 \\
\hline \multirow{2}{*}{\multicolumn{3}{|c|}{ Hospitals }} \\
\hline & & \\
\hline St Mary Le Bow Infirmary & 1 & - \\
\hline Borough Hospitals & 2 & - \\
\hline Charing Cross Hospital & - & 3 \\
\hline St George's Hospital & 5 & 9 \\
\hline Guy's Hospital & 36 & 25 \\
\hline St Bartholomew's & 20 & 19 \\
\hline University College Hospital & - & 28 \\
\hline London Hospital & 10 & 16 \\
\hline King's College Hospital & - & 12 \\
\hline St Thomas's Hospital & $\overline{14}$ & 2 \\
\hline Middlesex Hospital & 8 & 4 \\
\hline Westminster Hospital & 1 & 2 \\
\hline N. London Hospital & 3 & - \\
\hline Total & 100 & 120 \\
\hline
\end{tabular}

Another change that gradually occurred during 1815-1858 was that the number of pupils who became Members of the Royal College of Surgeons gradually increased. In the period up to 1837 , only 38.5 per cent of those qualifying with the LSA also took the examination for MRCS. After 1837, sixty-eight per cent of the pupils obtained both qualifications. A few of them also went on to obtain other qualifications - twenty (six per cent) became Fellows of the Royal College of Surgeons either by election or examination and twenty-one (6.4 per cent) became MDs (St Andrews 8, Edinburgh 4, Kings College Aberdeen 4, London, Glasgow, Heidelberg and Erlangen 1 each, and one unnamed university).

\section{THE CAREERS ${ }^{61}$}

The careers available to these men on qualification must have depended to some extent on the vacancies that occurred. According to White's Directory in 1844, there 
were 174 surgeons practising in Suffolk. If each appointment had been filled twice in the course of forty-three years (1815-1858), then there would have been ample vacancies to accommodate all the qualifying surgeons. In fact, the number of vacancies occurring in Suffolk during this period proved to be less than 200 - a possible reason for this was an unexpected longevity amongst some Suffolk surgeons, as eighty-three of them had an average working life of 38.4 years. It was also expected that the number who trained in Suffolk but worked after qualification in neighbouring counties would roughly equal those who trained in these counties but came to work in Suffolk. In fact, forty surgeons trained in Suffolk then worked in Norfolk (twentyfour), Essex (thirteen), and Cambridge (three), while only twenty-eight moved in the opposite direction.

Of the $\mathbf{3 3 0}$ who were apprenticed in Suffolk, the careers of 302 have been traced. Of these, one died within a few weeks of qualification, 131 (43.4 per cent) practised throughout their lives in Suffolk, and a further fourteen (4.6 per cent) practised for some years in Suffolk before settling elsewhere (five in London, two in Essex, one each in Birmingham, Slough, Norwich, Hertford, Staffordshire, Herefordshire, and Kent). Thus just under half of the Suffolk trainees (forty-eight per cent) returned to the county to practise.

As most of these men had completed their training in London, it is not surprising that twenty-nine (9.6 per cent) stayed in London permanently. Thirteen (4.3 per cent) practised in other towns, forty-one (13.6 per cent) somewhere in the Eastern Counties, and a further forty-one (13.6 per cent) scattered in other parts of rural England (Table 4).

At a time when the British Empire was expanding, nineteen (6.29 per cent) joined the services, six in the army, four in the navy, five in the Indian Medical Service, and four in the East India Company. Thirteen (4.3 per cent) were more adventurous and emigrated, six to Australia and one each to Africa, Canada, Barbados, USA, Gibraltar, Panama, and France.

The most adventurous of all the Suffolk surgical apprentices was Zachariah Poole, who is not included in these figures as he died before he could qualify. He joined Lord Amherst's expedition to China in 1816 as apprentice to Clarke Abel, the surgeon and naturalist to the expedition.62 (Abel had been a surgeon in Suffolk 1812-1815, and was married to Poole's sister.) Poole completed the journey but contracted an unidentified disease and returned to Suffolk to die on 29 March 1819, aged twenty. ${ }^{63}$

61 The careers of the Suffolk apprentices have been traced from the following sources: Ipswich Journal, 1815-1868; Medical Directory, 1847-1900; William White's Directory of Suffolk, 1844, 1855, 1874, and 1885 eds.; DNB; Munk, op. cit., note 22 above; Plarr, op. cit., note 36 above; S. H. A. Hervey, Biographical list of boys educated at King Edward VIth free grammar school, Bury St Edmunds, from 1550 to 1900 , Suffolk Green Book No. 13, Bury St Edmunds, 1908; W. Kelly \& Co., Post Office directory of the nine counties (Cambridgeshire, Norfolk, Suffolk, Essex, Hertfordshire, Kent, Middlesex, Surrey, and Sussex), London, 1846 and 1892; C. Partridge, Suffolk churchyard inscriptions. Copied from the Darby transcription 1825-1846, reprinted from the Suffolk Institute of Archaeology and Natural History, Part 1 (1913), Part II (1920), Part III (1923); Johnston, op. cit., note 48 above.

${ }^{62} \mathrm{C}$. Abel, Narrative of a journey in the interior of China and of a voyage to and from that country in 1816-1817, London, Longman, Hurst, Rees, Orme \& Brown, 1818.

${ }^{63}$ Ipswich Journal, 3 A pril 1819. 


\section{D. van Zwanenberg}

\begin{tabular}{|c|c|c|c|}
\hline & $\mathrm{CA}^{-}$ & $\begin{array}{l}\text { ABLE } 4 \\
\text { OF PRACTICES }\end{array}$ & \\
\hline Towns & & Counties & \\
\hline London & 29 & Suffolk & 145 \\
\hline Liverpool & 4 & Eastern Counties & \\
\hline Birmingham & 2 & Essex, Cambridge, Norfolk & 41 \\
\hline Bath & 1 & Kent & 11 \\
\hline Brighton & 1 & Bucks & 5 \\
\hline Darlington & 1 & Warwick & 5 \\
\hline Leicester & 1 & Middlesex & 4 \\
\hline Newcastle & 1 & Surrey & 4 \\
\hline Oxford & 1 & Herts & 2 \\
\hline Reading & 1 & Hunts & 2 \\
\hline & 一 & Yorks & 2 \\
\hline Total & 42 & Beds & \\
\hline & $=$ & Hants & \\
\hline & & Lancs & leach \\
\hline & & Northants & Teach \\
\hline & & Staffs & \\
\hline & & Sussex J & \\
\hline Died & 1 & & \\
\hline Services & 19 & & \\
\hline Emigrated & 13 & & \\
\hline
\end{tabular}

The figures may underestimate the number who emigrated as a result of a surplus of surgeons qualifying in Suffolk. At least one apprentice (R. R. Carley) returned to Suffolk to take over his master's practice so that the said master ( $R$. Alling) could emigrate with all his family to Canada, where he became successful both as a doctor and a businessman. ${ }^{64}$

\section{FAMILY PRACTICES}

The knowledge and experience that a man obtained over the years as a surgeon could be regarded as a family asset which could be passed to the next generation by taking a young relative as an apprentice. Of the $\mathbf{3 3 0}$ apprentices investigated, no fewer than eighty (twenty-four per cent) were apprenticed to their fathers, thirteen (3.9 per cent) to an elder brother or uncle with same surname as the apprentice, and four to an uncle on the mother's side..$^{65}$ In all, therefore, ninety-seven (29.1 per cent) of the pupils were apprenticed to close relatives. The other family asset that could be passed on to an apprentice was the goodwill and premises etc., of the actual practice. However, Table 5 shows that the numbers of apprentices who actually followed in their fathers' footsteps were far less than those who had been trained by their fathers. Only fortythree (thirteen per cent) carried on such a family tradition, but in some families this was repeated for several generations. In Suffolk, the best known of such surgical families were the Crowfoots, who practised in Beccles ${ }^{66}$ and supplied five surgeons spanning four generations, giving continuous service to the people of that town from

at Ibid., 14 October 1848.

os It was the custom for the son to use his mother's maiden name as his second Christian name. These four apprentices therefore had second Christian names which were the same as their trainers' surnames.

6 Crowfoot, op. cit., note 43 above. 
1792 to 1918. Such families may have led historians to over-emphasize the family influence of surgical practice, since this investigation has shown that 233 (70.6 per cent) of the pupils were not apprenticed to near relatives.

The apprentices were drawn from all parts of the middle classes. In addition to the eighty who came from surgical families, the father's occupation has been ascertained for another seventy-six. Table 6 shows that some of the fathers were clergymen and gentlemen, while some were merely artisans or tradesmen. Twenty-one were listed as the sons of widows.

TABLE 5

CAREER OF APPRENTICE WHEN HIS FATHER WAS AN APOTHECARY

If father was the trainer:

(a) Number of sons who took on father's practice

(b) Number of sons who took practice elsewhere in Suffolk

(c) Number of sons who took practice outside Suffolk

If father not the trainer:

Number of sons who were apprenticed to apothecaries

TABLE 6

OCCUPATION OF APPRENTICE'S FATHER

$\begin{array}{lrll}\text { Clergyman } & 23 & \text { Solicitor } & 5 \\ \text { Farmer } & 13 & \text { Miller } & 3 \\ \text { Gentleman } & 9 & \text { Ironmonger } & 3\end{array}$

And one each of the following:

Bank Clerk

Brewer

Brickmaker

Builder

Cabinet-maker

Cordwainer

Clerk

Druggist
Fish-curer
Hatter
Maltster
Merchant
Oatmeal manufacturer
Pipe-maker

Druggist

Hatter

Maltster

Oatmeal manufacturer

Pipe-make
Printer
Soap manufacturer
Silversmith
Schoolmaster
Treasurer of Town Council
Veterinary surgeon

\section{COMMENT}

The training that these men received allowed them to work as surgeon apothecaries throughout England, in India, in the services, and elsewhere in the world. The variety of work that they undertook was also extensive. Many of them were general practitioners, but two of them became medical superintendents of county asylums ( $F$. Fitch for Cheshire, W. P. Kirkman for Kent) and three physicians to private madhouses (J. B. Bryan, R. Pedgrift, R. E. Martin). Edwin Lankester became famous as Medical Officer of Health and Coroner for Westminster, a noted medical reformer. J. C. Burrows, a surgeon of Brighton, was knighted more for his political services than his surgical skill, and $\mathrm{H}$. Ancell became a lecturer in medical jurisprudence and surgeon to the London Police Force.

Two, at least, deserted the practice of medicine, one to be a farmer and the other a wholesale druggist. Three had senior appointments during the Crimean War: E. Haward was on the surgical staff at Scutari; S. D. Bird was officer in charge of the Turkish Military Hospital at Varna; and H. C. Wilkin was surgeon in charge of the transport ship Argo. 


\section{D. van Zwanenberg}

There was considerable variability in the lives of those who joined the services. $\mathbf{N}$. Collyer died at Cawnpore in the Indian Mutiny, but R. D. Mason became a rearadmiral as Inspector General of Hospitals and Fleets of the Royal Navy and J. A. Marston became Surgeon General to the Army in 1889 and an honorary surgeon to Queen Victoria. S. Piper joined the Lancers, was severely wounded in the chest in the campaign against Don Carlos, and later became Surgeon to the Darlington Hospital.

Sam Reynolds, who emigrated to Australia and made a successful life for himself and his family, was the only one to become a subject of a full-length biography. ${ }^{67}$

Thirteen of the surgeons who returned to Suffolk were elected to the staff of their local voluntary hospitals, as were twenty of those who practised outside Suffolk.

The Apothecaries' Act and the granting of the Licence of the Society of Apothecaries has been viewed variously by medical historians. It has been seen as part of the great reform movement, ${ }^{68}$ as a great stimulus to medical education, ${ }^{69}$ and as a means whereby the Royal College of Physicians maintained a superiority in the medical profession. ${ }^{70}$ This study has shown that the Apothecaries' Act did achieve one of its aims at least. It granted successful candidates a licence to practise. Even if most of their training had been in an obscure and isolated village, those who obtained the LSA could practise anywhere in England, the Services, or British territories overseas and could enter any of the specialist parts of the profession which were then beginning.

This study has also demonstrated some of the shortcomings of the apprenticeship system in which, unless the master made special arrangements, the pupil could live a very isolated existence for five years, missing the companionship of colleagues and the stimulation it can provide. It has also shown that medical practice in Suffolk in the first half of the nineteenth century was fairly parochial, most of the vacancies that occurred were filled by men who had trained in Suffolk or neighbouring counties. The fact that there were only about 200 vacancies for the 300 or so men who qualified during this period may have been responsible for scattering Suffolk-trained surgeons throughout England and overseas. It would be interesting to know if similar circumstances occurred in other rural counties.

\section{SUMMARY}

An attempt has been made to trace the 330 apprentices to apothecaries who completed their apprenticeship in Suffolk in the years 1815-1858 through their training to their eventual appointments. It was discovered that less than half of these men returned to Suffolk to practise but the licence of the Society of Apothecaries allowed the others to practise throughout England, in the services, and in territories overseas.

The study demonstrates some of the problems of the apprenticeship system.

\section{ACKNOWLEDGEMENTS}

I would like to thank Mrs Hewitt, the Medical Librarian to the Ipswich Hospital, Mr F. Sargent, the Suffolk County Archivist, and all the staff of the Suffolk Record Office for helping me trace these apprentices; Mrs Rodwell for lending me J. Gillison's book (note 76); my wife for her encouragement; my secretary Miss J. Ridout for typing the manuscript; and J. Dickson FRCS, for kindly reading the typescript and giving advice.

67 J. Gillison, Colonial doctor and his town, Melbourne, Cypress Books, 1974.

6 Sir Alexander M. Carr-Saunders and P. A. Wilson, The professions, Oxford, Clarendon Press, 1933, p. 78; F. N. L. Poynter, 'The centenary of the General Medical Council', Br. med. J., 1958, ii: 1245.

o W. H. G. Armytage, Civic universities, London, Ernest Benn, 1955, p. 78; Sir Zachary Cope, 'The influence of the Society of Apothecaries on medical education', Br. med. J., 1956, i: 1-6.

${ }^{70}$ Holloway, op. cit., note 26 above. 